International Journal of English Literature and Social Sciences
Vol-6, Issue-4; Jul-Aug, 2021

Peer-Reviewed Journal

\title{
Social Discontent and Oscar Wilde
}

\author{
Dr. Alka Bansal
}

Head, Dept. of English, S.D. (PG) College, Muzaffarnagar (U.P.), India

Received: 01 Jun 2021; Received in revised form: 03 Jul 2021; Accepted: 10 Jul 2021; Available online: 17 Jul 2021 (C)2021 The Author(s). Published by Infogain Publication. This is an open access article under the CC BY license (https://creativecommons.org/licenses/by/4.0/).

\begin{abstract}
Oscar Wilde, the most often quoted writer after Shakespeare possessed a keen insight and good judgment of people and society of his times. His comedy of manners or 'Society plays' as they are called in the literary circles are replete with criticism of his contemporary society. His comedies display the hypocrisy, the shallowness and artificiality of his society which seems to be hidden under a façade of respectability and aristocracy. Wilde seems to be fed up with these aspects of his society. Farce and Satire are the weapons with which he strikes his chief target, the upper-class society that is the London society, which is considered the 'Mecca' of the fashionable and the affluent. This is the society which he observed closely. He does not hang back to portray the snobbery, the corruption, fraud, the idleness and the lack of genuine moral scruples. He strives to mirror the manners of his society which was permeating with double standards, bubbling with depravity and was full of 'beautiful idiots' and 'brilliant lunatics'.
\end{abstract}

Keywords-Hypocrisy, Snobbery, Morality, Shallowness, Victorian society.

Oscar Wilde is acclaimed for his unconventional and vibrant writings that constitute a scintillating contribution to literature. He has a permanent niche in the literature of the world. His plays especially his social comedies are the most exquisite product of all his writings. Oscar Wilde wrote plays at the fag end of the nineteenth century when the notion of morality and society were swiftly revamping. His plays, chiefly social comedies, deal with the criticism of society, particularly the upper-class aristocratic society. Wilde does not approve of the growing lack of morals and disregard for traditions that was rampant in his contemporary society.

His distinguished art reposes in his dramatic portrayals of Victorian society. Wilde who had easy access to aristocracy, aimed at presenting as sharp a picture as he could convey of this fashionable, smug aristocratic world. His picture of society is indeed based on fact and reality. Wilde portrayed what he observed around him and as such he is neither satirizing nor very seriously moralizing. He exhibits vanity, prudery, hypocrisy and the double standard and the dearth of moral values in society.

Even a cursory analysis of Oscar Wilde as a social critic manifests that his criticism of society was at its zenith towards the beginning of his career when he wrote The Soul of Man Under Socialism. It suffered a setback towards the middle of his career when he was at the height of popularity. In the hey-days of his success, he seemed rather turn away from his social ideals. But towards the end of his career, he again turned back towards his social ideals which he used to profess. Wilde had suffered a lot in his life because of the dual standards and smug attitude of contemporary society.

The Soul of Man under Socialism is Wilde's only social tract. In this pamphlet, he attacked the general attitude of philanthropists who try to change or improve man from without. It is only by developing himself that a man can be of any use, either to himself or others. Wilde's epigrammatic style enables him to convey, in a phrase, a social justice which a more ponderous thinker might have needed a chapter to build up by solemn argument:

Wilde demands for every man the rights of individual development, which up to now only a few scholars and artists have enjoyed. On the so-called 'virtues of the poor' he is particularly eloquent and acute. The best of the poor, he contends, 
far from being grateful for charity are 'ungrateful, discontented and rebellious

(Ellmann 152).

Later on in the essay, Wilde mounts an open attack on the very idea of government. The Soul of Man under Socialism represented Wilde's real social beliefs. It mirrored Wilde's discontent with society and gave a picture of the kind of the world in which he would like men to live.

With the writing of the novel The Picture of Dorian Gray and his famous social comedies, Wilde climbed the highest pedestal of popularity. In his hey-days of success, there came a change in attitude towards society. The success of his plays, with their earnings, turned his head, and there is no doubt that for at least two years he lived very selfishly and then the worst side of his character came to surface in arrogance and inconsiderate self-indulgence.

Yet even at this period, his writings contain a powerful element of social criticism. The English upper classes represented in his plays are caricatured with clear hostility and Wilde does not hesitate to pillory their corruption, their shallowness, their snobbery, their lack of genuine moral scruples. Here and there he inserts epigrams that show his contempt for their social attitude. As he writes; "A man who moralises is usually a hypocrite, and a woman who moralise is invariably plain" (Epigrams 11), another example is "People nowadays are so absolutely superficial that they don't understand the philosophy of the superficial" (Epigrams 28).

In all his social comedies we can trace out the criticism of contemporary society. In Lady Windermere's Fan and A Woman of No Importance, he poses the social problem of the inequality between men and women in modern society and the ruthlessness of the conventional social code towards the individual. Wilde was against the existence of one law for men and one for women and would prefer to see no law for anybody.

Wilde's first comedy, Lady Windermere's Fan presents a graphic picture of the contemporary aristocratic society in which he lived. The kind of society he observed around him is brought into sharp relief, particularly in the portrayal of the party scene held to felicitate Lady Windermere on the occasion of her birthday. Lady Windermere, as Wilde shows, considers her party to be very select and is therefore extremely fastidious in the choice of her guests. Little wonder then, that a rather peculiar bunch conglomerate at her party.

There is the Duchess of Berwick, a corrupt and malignant gossipmonger, in hot pursuit of a wealthy Australian for her dull daughter, Agatha. Along with her is her brother Lord Augustus Lorton, who cannot remember whether he has been twice married and once divorced or twice divorced once married. So are lady Plymdale and her current lover, Mr Cecil Dumby. Lord Darlington, renowned rip and rampant with desire for Lady Windermere herself is another guest. If these are the people who are to be found in morally select and exclusive houses, one can well imagine the sort of people that could be found in less carefully conducted houses. Duchess of Berwick rightly says, "I don't know what society is coming to. The most dreadful people seem to go everywhere" (Wilde 374).

The people at the party are smart and expert in the language of badinage, quips and apophthegms. Lord Darlington is a perfect example of it. He artfully talks to Lady Windermere to advance his suit for her seduction. He tells her :

Oh, nowadays so many conceited people go about in society pretending to be good, that I think it shows rather a sweet and modest disposition to pretend to be bad. Besides, there is this to be said. If you pretend to be good, the world takes you very seriously. If you pretend to be bad, it doesn't. Such is the astounding stupidity of optimism (Wilde 371-372).

Wilde's criticism of society is aimed at exposing the underlying shallowness and shame which is concealed under a facade of respectability and aristocracy. He shows each character to be a meddlesome busybody who is out to ruin and disorient the lives of the others. Whether it is Lord Darlington or Mrs Erlynne, Illingworth or the pompous Duchess of Berwick, each is endowed with the special capacity of invading upon the privacy of others. Not content with their station in life they seek entertainment by poking and bragging into the affairs of others quite nonchalantly leading them to the brink of ruin. Each one of them is quick to dole out sagacious verbiage, quite unmindful of their follies, weaknesses or inconsistencies.

The conventionally conceived play, A Women of No Importance which has a feminist plot, has indeed a general atmosphere of social protest, not only in the satirical and bitter attitude towards the upper classes but also in the main plot which is built around a social problem already sketched in Lady Windermere's Fan of the inequality of men and women in modem society and the ruthlessness of the conventional social code towards the individual who, deliberately or unwillingly acts against its arbitrary laws. 
The theme is presented conventionally, in the differing lives of Lord Illingworth, the successful and ruthless public figure and Mrs Arbuthnot, by whom Illingworth had a child many years before. The son of this transitory union, grown into an intelligent youth attracts, Illingworth's interest, so far that he proposes to take him as his secretary. In this way are shown the contrasting fates of the man and the woman; Lord Illingworth who goes through life gaily and unscathed by his cynical refusal to protect the mother of his child from the hostility of conventional society by marrying her; Mrs Arbuthnot, enduring a lonely life of guilt and bitterness and now faced by the last humiliation of seeing her son's wish to go away with the man who has been the cause of her life-long misery.

In A Woman of No Importance, Wilde appears to have offered criticism on aristocratic life, ultimately defeating the cynical Lord Illingworth. He represents the typical aristocrat, who has lost faith in goodness or morality and is an idol of depravity and vulgarity. Lord Illingworth's innate vulgarity is revealed through a scene between him and Mrs Allonby in which the lady dares him to attempt the little Puritan's virtue. He wagers that he will undo the girl with a single kiss. His son who is in love with this girl turns against him and thus Illingworth and his belated paternal feelings are defeated.

Lord Illingworth's views on life are very shallow. He says to his son Gerald, "To get into the best society, nowadays, one has either to feed people, amuse people or shock people, that is all!" (Wilde 445). He explains to Gerald that a man who can dominate a London dinner table can dominate the world. But Illingworth's badly emphatic upper-class egotism is injured at the end of the play when Mrs Arbuthnot strikes him across the face with one of his gloves. This defeat of Illingworth, who had assumed the manner of a professional rake, shows disapproval of such behaviour and does not glorify this outlook of aristocrats.

London society, the Mecca of the fashionable and the rich, seems the continual target of Wilde's attack. The vein of social criticism in An Ideal Husband is as deep as in A Women of No Importance. According to Sir Robert Chiltern's sister Mabel, London society "is entirely composed now of beautiful idiots and brilliant Lunatics" (Wilde 475). This casual remark of Mabel Chiltern points more than the eye can see. It exposes the humbug and snobbery that appears to be cast over the entire society.

Nothing could be more derogatory or demeaning than this quite a heated outburst by Lord Caversham who cannot stand the London society. He feels the English society has gone to the dogs, a lot of damned nobodies talking about nothing. The depth of falsehood, deceit and shallow pretensions can be seen in Mrs Cheveley's opinion that "London society was entirely made up of dowdies and dandies(Wilde 476) who lead an idle life. Their life was related only to love and sex. They preferred not to disturb their shun complacency by the thought of any serious commitment or purpose.

In the late nineteenth century glamorous life, it was considered most fashionable to marry as often as one could. The number of women deserting their husbands for losers was large. In their craving for jewels. scents and champagne, they could even blackmail people. As these women could not maintain the sanctity of marriage it resulted in the birth of illegitimate children and various problems which an unmarried mother has to face. Thus by presenting this aspect of society, Wilde could criticize the manners and morals of the age. Not only the males but even the females had lost all sense of purity and morality. The English society was like a puddle in which all sorts of vices were fermenting.

An Ideal Husband poses the problem of corruption and fraud which was rampant in English society, especially in political life. In Mrs Cheveley's view, politics is the only field left for women who are under thirty, since it was not considered fashionable to flirt till one is thirty-five or to be romantic till one is forty-five. This view again proves the shallowness of the society which had, it seems just two fields open for its memberspolitics and romance.

Wilde sketches a picture of the political life of the society of his times. Society was full of people who build their fortunes based on fraud. Some of them remained fraudulent throughout their life while some like Sir Robert who has committed a mistake once in their life, do not intend to repeat it and are repentant of their folly. But even such people have to face problems on account of their single misdeed. There is the constant fear of public disgrace and social boycott.

Sir Robert Chiltern had begun his career by selling state secrets to an international financier and from the money, he had gained by this initial corruption, rises to the heights of a political career. When he reaches this position, his past is used as a means of blackmail by a woman who wishes him to support a fraudulent canal scheme and thus assure the success of its promoters. He is saved from this threat not by his virtues but by his friend Lord Goring, applying counter trickery to Mrs Cheveley, the blackmailer.

Thus Wilde makes it explicit that in political life fraud and hypocrisy always win the prize. Wilde showed a consistently hostile attitude towards politics and 
politicians. In An Ideal Husband Wilde's strongly critical attitude towards political life occurs in many deliberate statements of opinion in various parts of the play. For instance, when Robert Chiltern is trying to prepare his wife for a revelation of his predicament, which he knows will shatter the pedestalled ideal she has always made of him he says to her :

Gertrude, truth is a very complex thing, and politics is a very complex business. There are wheels within wheels. One may be under certain obligations to people that one must pay. Sooner or later in political life, one has to compromise. Everyone does (Wilde 486).

By pointing out one case of fraud in political life, Wilde has only hinted at what was true of many prosperous politicians. The English politicians lacked morality. But with their modern mania for morality, they had to pose as a paragon of purity, incorruptibility, which resulted in their disappearance from the political scene.

In The Importance of Being Earnest Wilde strives to depict the harsh realities of contemporary society employing irony and sarcasm. He becomes successful by portraying the two main characters Algernon and John focus on the most trivial things instead of emphasizing the most significant issues. Both characters call themselves Ernest. But there is hardly any earnestness or honesty in their disposition. The pun is intended here by the author. He also hits at the hypocrisy of marriage and sentiments. He has portrayed the superficiality and shallowness of London society. The play contains in Lady Bracknell, a satire on the snobbish values of the upper classes, while Miss Prism and doctor Chasuble represent respectively Wilde's contempt for the educational system and the Church of his day.

Algernon holds queer opinions about marriage "Divorces are made in Heaven" (Wilde 322) and "girls never marry the men they flirt with. Girls don't think it right" (Wilde 323) Not only Algernon but even Gwendolen thinks that if Lady Bracknell should "prevent us from becoming man and wife, and I may marry someone else, and marry often, nothing that she can possibly do can alter my eternal devotion to you" (Wilde 336).

Wilde shows that people retain the gem-like glitter but remain impoverished at heart. They lack real human warmth. Gwendolen loves Jack just because she has an irresistible fascination for the name Ernest, Jack loved her in the name of Ernest. Gwendolen tells Jack that she could only love him whose name was Ernest. She says, "my ideal has always been to love some one of the name of
Ernest. There is something in that name that inspires absolute confidence" (Wilde 329).

In this comedy, Wilde presents a strictly reasonable satire on worldly women with daughters to settle through Lady Bracknell's interview with Jack Worthing. After she has caught Jack in the act of proposing to her daughter she informs him that he is not down on her list of eligible young men, but she could enter his name if his answers fulfilled her requirements. Thus the interview begins and it unveils the shallowness, shame and hypocrisy of society. When Jack confesses to Lady Bracknell that he smokes. "I am glad to hear it," she says, "A man should always have an occupation of some kind. There are far too many idle men in London as it is" (Wilde 331).

During her interview with Jack Worthing, she learns that Jack had lost his parents when he was very young and he didn't know who he was by birth. Lady Bracknell demands credentials of Jack's lineage. She says; "I would strongly advise you, Mr. Worthing, to try and acquire some relations as soon as possible, and to make a definite effort to produce at any rate one parent, of either sex, before the season is quite over" (Wilde 333).

It is indeed worth noticing that these English women who do not care for social values and are often ready to desert their children and husbands for the sake of lovers become so cautious when the marriage of their daughters is in question. They, who live in a society that is bubbling with depravity, demand the credentials of the lineage of their would-be sons-in-law. Wilde has conceived Lady Bracknell as a gross type of social snob, surrounded by sham respectability. She represents a typical Victorian woman who is arrogant, ruthless and conservative.

In his social comedies, Wilde seems to completely ignore the world beyond the fashionable and the aristocratic. However, it will be a misreading of his work to call it purely fantastic and unreal. Wilde who appeared devoted to portraying the superficial glamour of society never lost sight of the weaknesses and lack of morals. Wilde who never was an active socialist like Shaw has not glorified the aristocracy in any of his plays. The aristocrats were always shown with some glaring defects in their character. In the aristocracy, conventions were raised to the level of ideas that served to mask their double standards. This was the society that had moved from the middle class to the higher class. Wilde's epigram; "I can resist everything except temptation" (Epigrams 29) befits this society but Wilde's aim was not wholly to expose his subjects to the attack from the public. 
Wilde offers criticism of his contemporary society through the medium of his comedies. His observations are conditioned by his obligations and temptations. He aims to mirror the manners, not to reform the morals of his day. Wilde, constantly divided in his desire to be accepted and praised by society, and in his contempt of its empty values "could not write as the ordinary satirist does, for where the satirist admires a social norm and ridicules deviation from it, the Wildean, dandy is himself a deviation and ridicules the social norm" (Granz 14).

Wilde's attitude to the social problems of his day may appear ambivalent but he does show an awareness of the artificiality and essential corruption of society in general. London society, according to Mabel Chiltern, even when it has immensely improved, is composed of 'beautiful idiots' and 'brilliant lunatics'. Mrs Erlynne's experiences tell her that there are just as many fools in society as there used to be. In Lord Caversham's opinion, it has gone to the dogs. Those who regard Wilde as a mere poseur will find in many such lines an abrasive censure on contemporary society. Thus he subjected contemporary social life to criticism and did what he could to expose corruption and hypocrisy.

\section{REFERENCES}

[1] Ellmann, R.; ed., Oscar Wilde: A Collection of Critical Essays. New Jersey: Prentice Hall, Inc., 1969.(print)

[2] "Epigrams of Oscar Wilde", Wordsworth Reference Series Hertfordshire: Wordsworth Editions Limited, 2007 (print).

[3] Granz, Arthur, 'The Dandical Drama, A Study of the Play of Oscar Wilde', quoted in San Juan, The Art of Oscar Wilde. (print)

[4] Wilde, Oscar. The Complete Works. London: Magpie Books, 1993.(print) 